http://kitaibelia.unideb.hu/

ISSN 2064-4507 (Online) • ISSN 1219-9672 (Print)

(C) Department of Botany, University of Debrecen, Hungary

23 (1): 3-7.; 2018

DOI: $10.17542 /$ kit.23.3

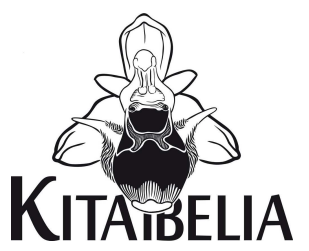

\title{
200 éve született Hazslinszky Frigyes Ágost
}

Szerkesztette:

TAKÁCS Attila

MTA-DE „Lendület” Evolúciós Filogenomikai Kutatócsoport

Debreceni Egyetem TTK Növénytani Tanszék

Mondhatunk-e bármi újdonságot két évszázad távlatában olyasvalakiről, akit kortársai, követői számos alkalommal megemlékezéseikben méltattak? Elfeledett életrajzi dokumentumok vagy a hagyaték feldolgozása nélkül aligha. Hazslinszky Frigyes esetében jelenleg nem állnak rendelkezésünkre az életét és munkásságát új megvilágításba helyező tények, talán mégsem haszontalan feleleveníteni vele kapcsolatos ismereteinket.

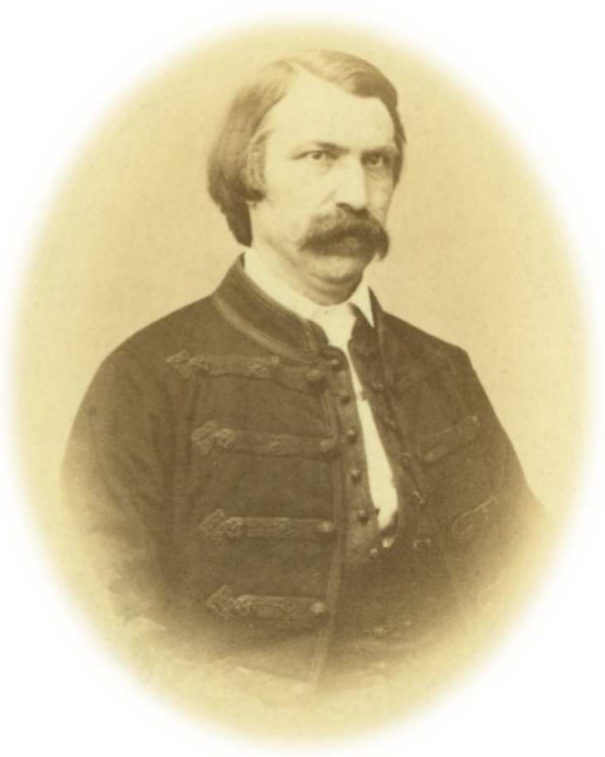

Hazslinszky Frigyes portréja a Magyar Tudományo Akadémia székházának avatása (1865) alkalmából megjelent díszalbumból (Schrecker Ignác felvétele, a Fővárosi Szabó Ervin Könyvtár jóvoltából)
A fővárostól távol, így a tudományos közélettől valamelyest elszigetelten élő, mégis eredményes tudós alakja mindenképp figyelemreméltó. Munkássága az akkori felfogás szerinti növényvilág szinte minden csoportjára kiterjedt: gombákról, kovaalgákról, mohákról, zuzmókról, hajtásos növényekről, ősnövényekről egyaránt jelentek meg tanulmányai hazai és nemzetközi folyóiratokban (elsősorban a Mathematikai és természettudományi közlemények, valamint az Österreichische Botanische Zeitschrift hasábjain). Bár valamennyi területen maradandót alkotott, az utókor elsősorban mikológusként emlékezik rá, és nemzetközi viszonylatban is ezirányú tevékenysége tette széles körben ismertté. Hazslinszkyt konzervatív fajfelfogás jellemezte, így az általa leírt taxonok száma viszonylag csekély. Gazdag életműve azonban masszív alapot biztosított az utókor részletes florisztikai és növényföldrajzi feltáró munkája számára. Erre építkezhettek az Eperjesi Evangélikus Kollégiumból kikerült tanítványai, így Fábry János (1830-1907), Hollós László (1859-1940), Jurányi Lajos (1837-1897), Lojka Hugó (1844-1887), Mágócsy-Dietz Sándor (1855-1945), Péterfi Márton (1875-1922), Richter Aladár (18681927), Simonkai Lajos (1851-1910). 


\section{Életútjának fóbb eseményei}

1818. január 6-án született a Szepes megyei Késmárkon, birtokait vesztett nemes, protestáns családban. Már gyermekkorában megmutatkozott a növényvilág iránti érdeklődése: szeretett kertészkedni, illetve a számára kedves virágokat könyvek lapjai közt szárította. A család háziorvosától vehetett kézbe elsőként botanikai szakkönyvet, Mathioli egyik művét. Elemi és középiskolai tanulmányait szülővárosában folytatta egy év kivételével, amikor Debrecenben magyar nyelvtudását fejlesztette (a családban németül beszéltek).

1838-1839 tanévben a Sárospataki Református Kollégiumban jogot tanult. Az itt töltött időszakban összeállított egy kompendiumot Das Linneisch Houtuynische Pflanzensystem címmel, a címben említett szerzők műveiben megjelent leírások és illusztrációk felhasználásával. Ezt a művét soha nem publikálta (kézirata megtalálható a Magyar Természettudományi Múzeum Tudománytörténeti Gyűjteményében), de a munka vélhetőleg nagyban hozzájárult Hazslinszky növényismeretének elmélyüléséhez.

1839-1841 között Késmárkon folytatta teológiai tanulmányait, egyidejűleg helyettes tanárként dolgozott.

1841-ben tanítványa, Mauks Károly kíséretében két hónapos kutatóútra indult Bártfáról Eperjes, a Közép-Tisza-vidék, Eger, Pest, a Balaton és Zákány érintésével Fiuméig, onnan Varasd, Rohonc, Pozsony, Nyitra, Selmec és Liptó érintésével tértek haza Késmárkra.

1842-1843 tanévben a Debreceni Református Kollégiumban növénytant és kémiát tanult (valószínűleg ebben az időszakban figyelhette meg és gyưjthette a város környékén az általa Anemone pratensis L. var. flavecens-nek nevezett növényt, amelyet ma Pulsatilla flavescens (Hazsl.) Borb. emend. Boros néven ismerünk).

1844-1845 tanévet a Bécsi Műszaki Egyetemen töltötte, geológiai, ásványtani, paleontológiai, kémiai, fizikai ismereteit bővítette. Hogy a magasan iskolázott személyeket érintő határátlépési nehézségeket elkerülje, elutazása előtt nyerges- és kerékgyártó mesterségből legényi vizsgát tett, s a határt ilyen minőségben lépte át.

1846-ban kötött házasságot Putz Teréziával.

1846-tól az Eperjesi Evangélikus Kollégiumban a természetrajz és a matematika nyilvános, rendes tanára. Emellett az intézmény pénztárnoka, 1884-1885-ben, illetve 18861887-ben igazgatója, megszakításokkal 1893-ig rektora. Az itt töltött majd' 50 éves pályáját végigkísérte az intézmény müködéséhez szükséges financiális feltételek megteremtéséért vívott harc.

1848. december 10-11.: tanártársaival és diákjaival részt vett a szabadságharc budaméri ütközetében (a téli hadjárat során a császáriak december 9-én elfoglalták Eperjest; a rögtönözve felállított honvédzászlóaljak Budamérnél próbálták feltartóztatni a Kassa és Miskolc irányába nyomuló csapatokat, sikertelenül).

1863-ban a Magyar Tudományos Akadémia levelező, 1872-ben rendes tagjává választották. 1888-ban a Királyi Magyar Természettudományi Társulat tiszteletbeli tagjává választották.

1890-ben Ferenc József a hazslini előnév adományozásával megerősíti a család régi nemességét (a család ősi birtokai a Sáros vármegyei Hazslin község környékén feküdtek, de ezeket a Rákóczi szabadságharc idején elvesztették).

1896. november 18-án Eperjesen hunyt el. Ravatalát a kollégiumban állították fel. A város temetőjének déli parcellájában helyezték örök nyugalomra. 


\section{Legjelentősebb művei}

1864 Éjszaki Magyarhon viránya. - Werfer Károly Acad. Könyvnyomdája, Kassa.

1867 Magyarország s társországai moszatviránya. - Mathematikai és természettudományi közlemények 5: 163-181.

1872 Magyarhon edényes növényeinek füvészeti kézikönyve. - Atheneum, Pest.

1875 Magyarhon hasgombái (Gasteromycetes). - Mathematikai és természettudományi közlemények 13: 1-24.

1876 Magyarhon üszökgombái és ragyái. - Mathematikai és természettudományi közlemények 14: 81-197.

1877 Magyarhon Myxogasterei. - Az Eperjesi Evang. Ker. Collegium Értesítője az 1876/7 isk. évekról. Eperjes, 1-34.

1881 Rendhagyó kög-gombák. - Értekezések a természettudományok köréből. XI. kötet, XIX. szám, A M. Tud. Akadémia Könyvkiadó-hivatala.

1884 A Magyar Birodalom zuzmó-flórája. - Királyi Magyar Természettudományi Társulat, Budapest.

1885 A Magyar Birodalom moh-flórája. - Királyi Magyar Természettudományi Társulat, Budapest.

1885 Magyarhon és társországainak szabályos dyscomicetjei (Discomycetes). Mathematikai és természettudományi közlemények 21: 175-287 + 12 tábla.

1893 A honi peronospora-félék. - Természetrajzi Füzetek 16: 29-33.

1894 Magyarhon s társországainak sphaeriái. - Mathematikai és természettudományi közlemények 25: 65-397.

1895 Magyarhon és társországainak húsos gombái. - Mathematikai és természettudományi közlemények 26: 155-369.

\section{Kortársak és utódok gondolatai Hazslinszky Frigyesről}

„Hazánk nem egy természetkedvelője s búvára neki köszönheti, hogy megkedvelte a természetet s számtalanok ő tőle nyerték az útbaigazítást a természettudományok tanulmányozására s önálló kutatásra."

„Az is egyik kiváló érdeme, hogy egyes vidékek növényvilágának ismertetésén s leírásán kívül ő a magyarhoni növényeknek rendszerbe foglalt ismertetésére törekedett s ilyfajta müveivel gazdagította irodalmunkat."

MAYER Endre (1897)

„Azt hiszem, nem túlozunk, ha azt állítjuk, hogy Hazslinszky működésének derekán a növényrendszertani disciplinák művelésének centruma nem egyetemeinken, hanem az eperjesi evang. collegiumban keresendő."

DEGEN Árpád (1910)

„Hazslinszky volt a magyar kryptogam flóra Kitaibel-je.”

MÁGóCSY-DiETZ Sándor (1899)

„Egy termékeny, szorgalmas élet egész tudományos termése 118 tudományos igényű monográfia és nagyobb dolgozat alakjában jelent meg, számos külföldi szaktársától nagy figyelemmel és elismeréssel kísérve (állítólag egy svéd mikológus csak azért tanult meg magyarul, hogy Hazslinszky magyar nyelvü műveit olvashassa).”

„Nemcsak a hazai mikológiai kutatások biztos és széles alapját vetette meg impozáns kutatásaival, hanem az egész kriptogám flóra és vegetáció vizsgálatainak is irányt és utat szabott. Ezért kell Hazslinszky életművére és példájára ma is fokozott tisztelettel és megbecsüléssel tekintenünk." 


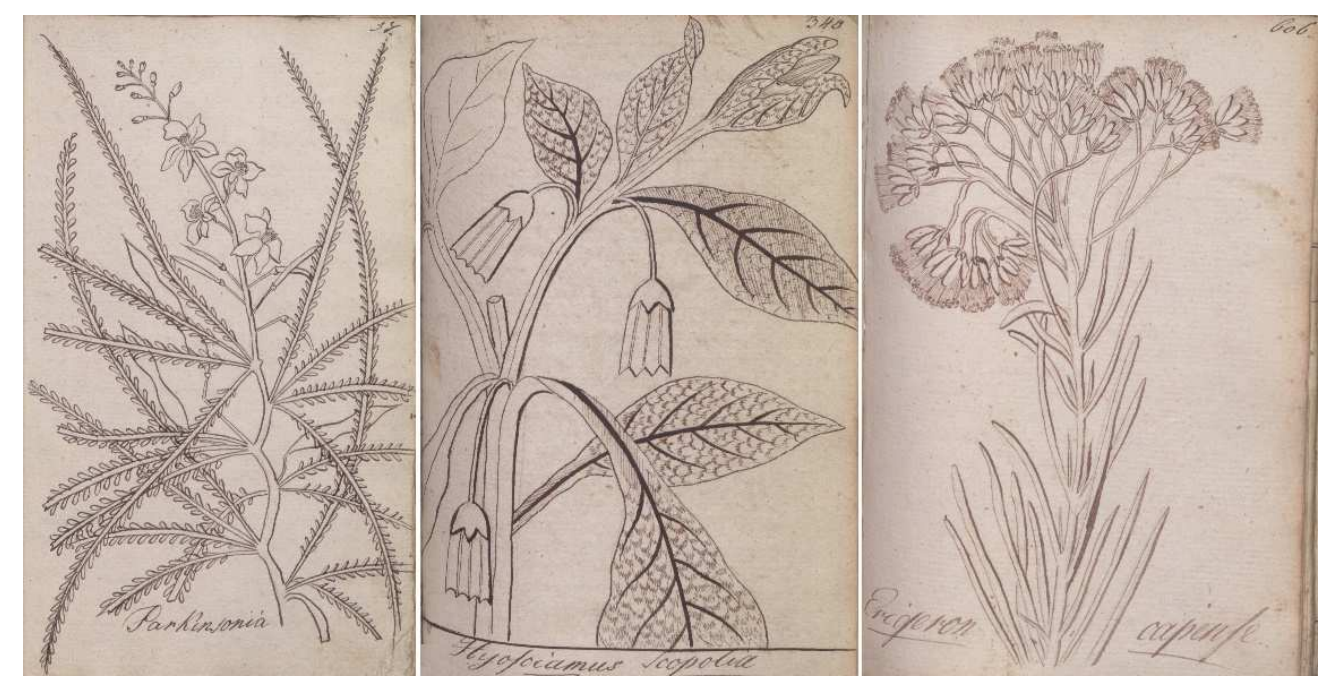

Das Linneisch Houtuynische Pflanzensystem c. munkájának három táblája (a MTM Tudománytörténeti gyűjteményéből)

\section{A Hazslinszky - Jermy - Mágócsy-Dietz - Tuzson család*}

Kevéssé ismert, hogy a 19-20. századi magyar botanika több jeles alakjának családi kapcsolatai összefonódnak. Hazslinszky Frigyes és testvére, Tamás, abba a Jermy családba házasodtak, amelynek a sarja volt Jermy Gusztáv, a kisújszállási gimnázium egykori tudós tanára, múzeális értékű természetrajzi gyűjteményének megalapozója. Hazslinszky felesége révén sógorbátyja lett Mágócsy-Dietz Sándornak (aki egyúttal tanítványa is volt az eperjesi kollégiumban). Később Mágócsy-Dietz lánya és Tuzson János a Kachelmann családba házasodva sógorságba, majd gyermekeik házassága révén komaságba kerültek egymással. Kiemelendő még Hazslinszky Frigyes unokája, Hazslinszky Bertalan is, aki a növényanatómia, állatorvosi növénytan, élelmiszermikroszkópia (elsősorban méz pollenanalitika) művelőjeként írta be magát a magyar botanika 20. századi történetébe.

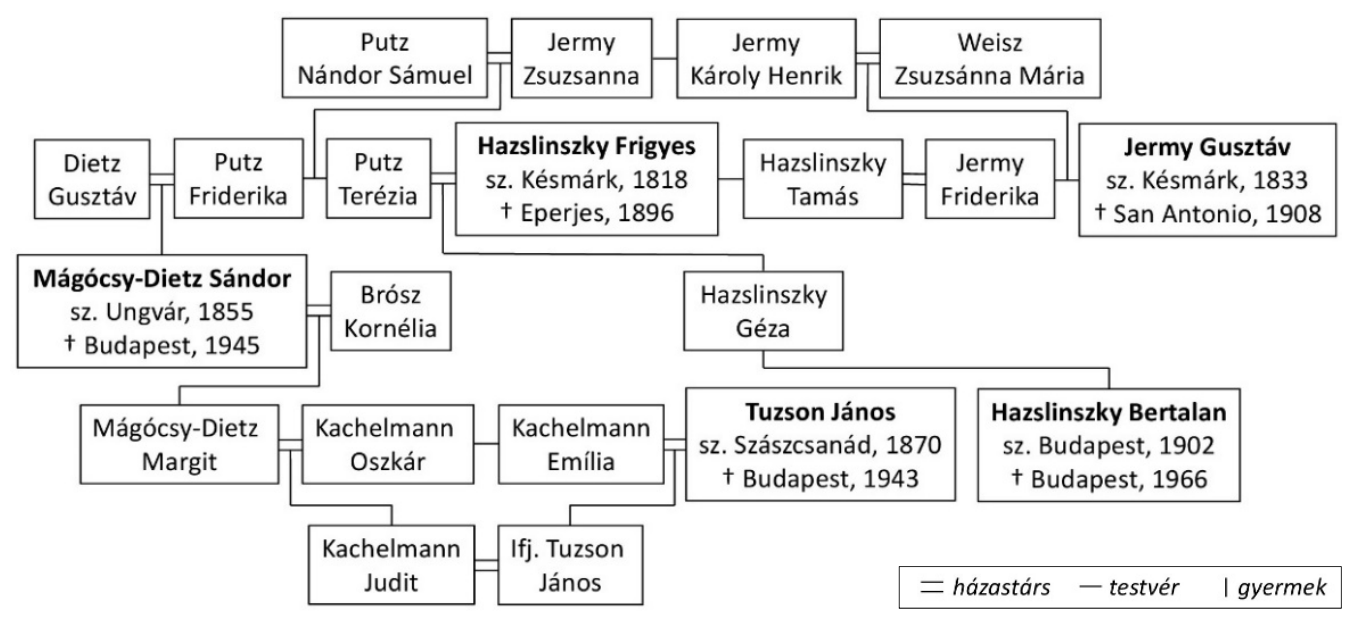

Hazslinszky Frigyes családfájának egyszerűsített vázlata, a család botanikus tagjainak kiemelésével

* Készült Koudela Pál munkáinak (2010, 2015), Ködmön Levente Gergely közléseinek és a FamilySearch (www.familysearch.org) adatainak felhasználásával. 


\section{Köszönetnyilvánítás}

Köszönöm Koscsó Jánosnak, Koudela Pálnak, Ködmön Levente Gergelynek, Molnár V. Attilának és Tuzson Balázsnak a megemlékezés kéziratának ellenőrzését, Sebestyén Rékának az MTM Tudománytörténeti Gyűjteményében őrzött Hazslinszky kézirat felkutatását, a Fővárosi Szabó Ervin Könyvtárnak szíves hozzájárulásukat a Hazslinszky portré felhasználásához.

Az Emberi Erőforrások Minisztériuma ÚNKP-17-4 kódszámú Új Nemzeti Kiválóság Programjának támogatásával készült.

\section{Felhasznált és Hazslinszky Frigyesről szóló további irodalom}

Allodiatoris I. (1962): Hazslinszky Frigyes (1818-1896). - Élővilág 7: 52-56.

Boros Á. (1969): Máramarosban - Hazslinszky Frigyes nyomában. - Búvár 14: 161-163.

DEGEN Á. (1910): Dr. Simonkai Lajos. - Magyar Botanikai Lapok 9: 2-13.

EGRI K. (2001): XIX. századi nagy magyar mikológusok a Felvidéken: Kalchbrenner Károly és Hazslinszky Frigyes. - Mikológiai közlemények 40: 145-154.

KALCHBRENNER K. (1872): Gallerie österreichischer Botaniker XVI. Friedrich A. Hazslinszky. Österreichische botanische Zeitschrift 22: 1-7.

KáLMÁN Gy. (1998): 180 éve született Hazslinszky Frigyes. - Természet 5: 260-261.

KÁRPÁTI Z. (1968): Hazslinszky Bertalan emlékezete. - Botanikai Közlemények 55: 149-152.

Koudela P. (2010): Mágócsy-Dietz Sándor - Mindennapi történet egy egyetemi tanárról. - L'Harmattan Kiadó. KoudeLA P. (2015): Civic gentry in Sáros county in the 19th century: the history of Hazslinyszky family, part I. - West Bohemian Historical Review 5: 29-50.

LENGYEL I. (1968): Hazslinszky Frigyes ismeretlen debreceni kapcsolata. - Acta biol. Debr. 6: 205-210.

MÁGócsY-DiETZ S. (1899): Hazslinszky Frigyes élete és működése. - Természettudományi közlöny 31 (pótfüzet): 50-64.

MAYER E. (1897): Hazslinszky Frigyes emlékezete. - Az eperjesi ág. ev. ker. Collegium étesítője pp. 1-33.

TóTH A. (2001): A kisújszállási Jermy Gusztáv Természetrajzi Szertár és Múzeum. - In: BARNA G. (szerk.), Társadalom, Kultúra, Természet. Tanulmányok a 60 éves Bellon Tibor tiszteletére. Karcag - Szeged Szolnok, pp. 279-287.

Somlyay L. (2000): A Pulsatilla flavescens (Hazsl.) Borb. emend. Boros prioritásának védelmében. Kitaibelia 5: 245-248.

UBRizsy G. (1968): Megemlékezés Hazslinszky Frigyesről, születése 150. évfordulóján. - Botanikai Közlemények 55: 145-148.

Beérkezett / received: 2018. 06. 01. • Elfogadva / accepted: 2018. 06. 25. 